\title{
The Change of Butonese Cultural Landscape in Negeri Kawa, Molucas
}

Komunitas: International Journal of Indonesian Society and Culture 9(1) (2017): 61-69

DOI:10.15294/komunitas.v9i1.5022 (C) 2017 Semarang State University, Indonesia p-ISSN 2086 - 5465 | e-ISSN 2460-7320 http://journal.unnes.ac.id/nju/index.php/komunitas

\section{Ray March Syahadat ${ }^{1}$ \\ ${ }^{1}$ Study Program of Landscape Architecture, Faculty of Civil Engineering and Planning, National Institute of Science and Technology, Indonesia}

Received: 6 February 2016; Accepted: 23 March 2017; Published: 30 September 2017

\begin{abstract}
As a maritime ethnic, Butonese people migrated to some places. A rather large amount of them are in Province of Maluku, Indonesia. This study aims at investigating Butonese cultural landscape in their new migrant region. Is there any different? If this study also aims to know social interaction among ethnics and how it affects Butonese cultural landscape dynamics. This study took place in Negeri Kawa, western part of Seram Regency, Maluku Province, on November 2015. The method used in the study was a qualitative method with in depth interview by snowball and triangulation technique, observation participation, focus group discussion (FGD), and literature study. The result showed that there is a different between Butonese cultural landscape in Buton and Negeri Kawa. Stereotype, presumption, and prejudice to Butonese people also occur. However, it is not always negative because from those three things, the process of acculturation and adaptation as a form of respect and prevention of Butonese culture can occur in Negeri Kawa.
\end{abstract}

\section{Keywords}

adaptation; acculturation; migration; Western Part of Seram; social interaction

\section{INTRODUCTION}

Butonese ethnic group is one of four ethnics which have strong maritime culture. Maritime culture of Butonese people is little different from most of other ethnic groups because they are not only fishermen and sailors but also farmers and traders (Hidayah 2015; Arifin 2015). The livelihood systems of Butonese are carried out simultaneously by a single same individual. This situation makes Butonese people survive and are able to migrate using their traditional boats.

Butonese villages are found in several areas in Indonesia such as in East Kalimantan, Central Sulawesi, Nusa Tenggara, Riau Islands, Papua and Maluku. In Malu$\mathrm{ku}$, along with Bugis and Makassar people, they are known as BBM trio which play an important role in the economic sector (Subair 2014). In Negeri Kawa, a village in West Seram Regency, Butonese people are settled in three of the five existing villages. In fact, two of which are inhabited by one hundred percent of Butonese people.

The research on the cultural landscape of Butonese is mostly done at the original place of Butonese people (the area of former kingdom of Buton Sultanate in South East Sulawesi). The report on the

\footnotetext{
Corresponding author

Bhumi Srengseng Indah Campus - ISTN,

JI. Moh. Kahfi II Jagakarsa, South Jakarta,

DKI Jakarta 12640

Email : Ray.arsitekturlanskap@istn.ac.id
} 
cultural landscape of Buton in the outside of their area is still lacking, whereas their number in the outside or migrant area is considerably big.

In addition, the study on interethnic interaction frequently discusses the interaction of social relations without seeing a change in the form of culture as a result of such interaction (Hidayat 2013; Kinasih 2013; Lestari 2013; Carnegie 2010; Bräuchler 2017). Therefore, this study aims at investigating how the cultural landscape of Butonese people in their migrating area; whether there is a difference or not. If there are some differences, what are they? Further, this study also tries to look at the interaction between ethnic groups in Negeri Kawa and how it affects the dynamics of the cultural landscape of Butonese people.

The research was conducted in $\mathrm{Ne}-$ geri Kawa, West Seram Regency, Maluku Province during November 2015 (Figure 1). The research employed qualitative approach. The data and information were collected through in-depth inter views, participation observation, focu $s$ group discussions (FGD) and literature studies. The informants were selected purposively using snowball technique and triangulation (three villages, three heads of custom and three social classes). The participants represented the people of the three villages that had Butonese ethnicity namely Kawa, Waeyoho and Pohon Batu Villages, as well as representatives of government and heads of village. The data and information obtained from data collection techniques and information was then presented descriptively.

\section{Negeri Kawa}

Landscape is a natural area that has certain characteristics and its existence can be enjoyed by the five human senses (Simonds and Starke 2006). Cultural landscape itself is a landscape in which there is human intervention so the interaction between nature and humankind is formed both in concrete and non-concrete forms. This long process of interaction creates extraordinary things to the group s civilization in studying natural phenomenon which is then applied in everyday life. Cultural landscape needs to be conserved because it is the identity of a community group that can be a pride of the civilization of a nation. Dynamic culture can threaten the loss of the cultural landscape. Negeri (village) Kawa is a custom village which is located on the western tip of Seram Island in Maluku Province. The landscape of Negeri Kawa is unique because it is formed spontaneously by three large ethnics spreading in five villages. The three ethnic groups are from Maluku, Butonese, and the most recent one is Javanese. Each ethnic group ss cultural landscape pattern forms their own character, although all of them remain under control of the King of Kawa as traditional leaders and chief of $\mathrm{Ne}-$ geri Kawa.

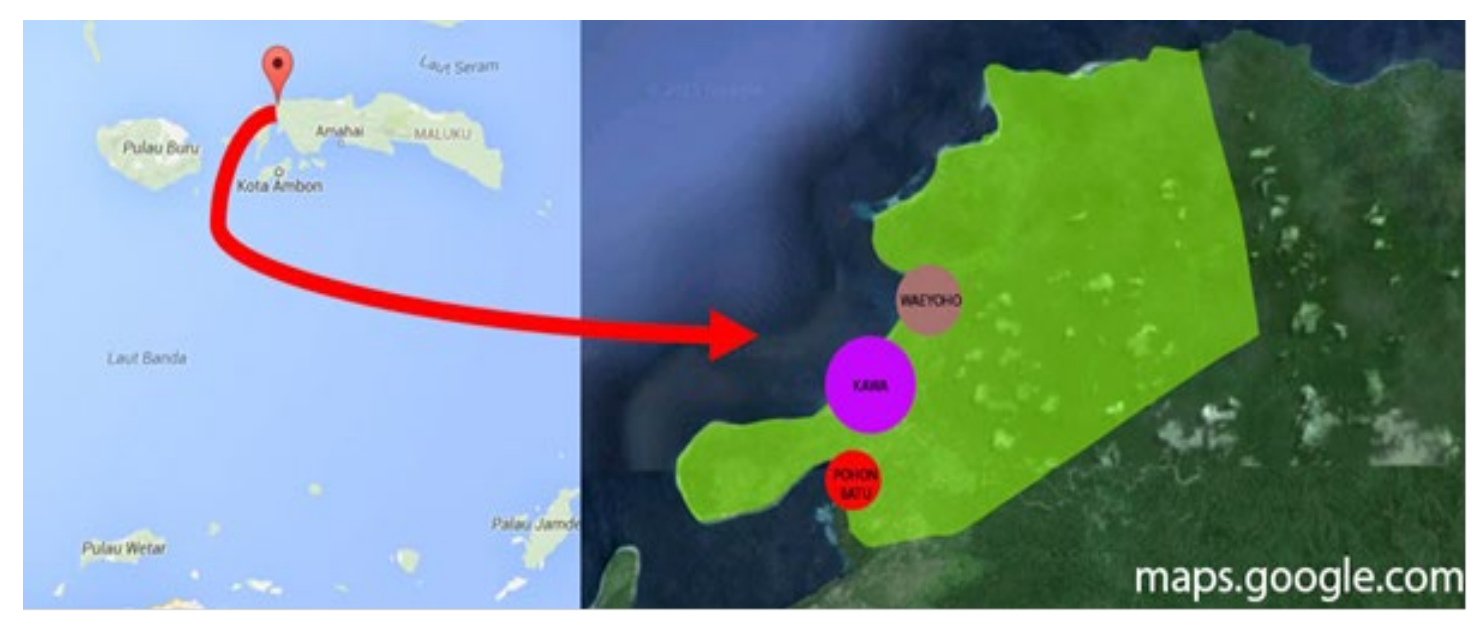

Figure 1. Research Sites in Negeri Kawa: Kawa, Waeyoho and Pohon Batu Villages 
The five villages in Negeri Kawa are Kawa, Waeyoho, Pohon Batu, Patinea, and Waetoso villages with a village center located in Kawa. The villages with one hundred percent of people working as fishermen are Waeyoho and Pohon Batu Villages. Nearly one hundred percent of fishermen in Negeri Kawa come from Buton. The existence of a separate community into several villages is because of the customary policy of $\mathrm{Ne}$ geri Kawa. Only local people (indigenous people) have land certificates, while all migrants both islanders and migrants have the use right toward their home land. This also applies to Butonese people who have settled there since the 1970 .

The indigenous people of Kawa come from two soa (clans/lineages) namely Nurue and Eli. Kawa community, also known as Kaba, came from the top of the Mai mountain range in a village called Rumasoal. The communities allegedly migrated because of group competition in the 12th century. The group continued to move from Sailebubui, then Lumalakai, until finally settled in Kaba. In the 19th century, Islam entered and Kaba people embraced Islam. They stayed at Kaba until 1963 and then moved to Sinakoko. In Sinakoko, they live together with immigrants from various regions in the kingdom of Buton, Southeast Sulawesi. Due to the influence of the dialect of the migrants and traders, Kaba is pronounced to be Kawa.

The Butonese themselves are thought to have been in Maluku especially West Seram since the 1600 . Ethnicity of $\mathrm{Bu}^{-}$ ton found in Negeri Kawa is quite diverse ranging from Wolio, Cia-Cia, Sampolawa, Tomia, Kaledupa and more. They migrate more because of their maritime culture, which likes to go fishing, trading and gardening. Therefore, migration does not happen at a time. Before the independence of Indonesia, the reason for those who partly chose to stay long in Maluku was because of the feeling of insecurity when they long sailed because of invaders attack.

They sailed to the eastward without no reason. Based on the historical records of some ancient manuscripts from Buton and the Netherlands, the journey of the Butone- se people to the east in the 16oos was for trading. One merchant woman from Buton named Wa Ode Wau exported the commodity of crafts under her business. These commodities included woven fabrics, gold, silver, diamonds, machetes swords, knives, crowbars and spear eyes. These items were in great demand by nutmeg and clove farmers in Maluku. Therefore, she sold them using a system of exchange with nutmeg (Myristica fragrans) and clove (Syzygium aromaticum).

In 1630-1692, Wa Ode Wau sailed her trade fleet of $300-600$ boats with a capacity of 10-6o tons and a workforce of not less than 3000 Butonese sailors. The amount was considerably huge in that time. The fleet not only sailed over Indonesian archipelago but also sailed east to west namely Makassar, Java, Sumatra, Johor and Singapore with different commodities. The era was the golden age of Butonese trading and it became the topic of discussion in Netherlands, Aceh, and Singapore (Marmun 2011). There are allegations that the Butonese in Maluku since the 1600 are the descendants of ancient sailors who tried to seize trading opportunities and eventually chose to settle in.

This allegation is supported by information from Rabani (2010), which states that Butonese people migrated to areas that have resources with high economic value. In the East, Butonese people went to Maluku, Tanimbar, Aru and northern Australia. They traded cloves, coffee, nutmeg, resin and copra. Koentjaraningrat (2005) also reported the movement of the Butonese people in the east to seek birds of paradise. No wonder that one of the custom clothing accessories from Butonese people is by wearing feathers of birds of paradise as reported Blair and Blair (2012) when an expedition ring of fire in the 1970's in Buton.

The migration of 1960 to the 1970 s was mainly because they looked for land that was free from pest attacks. In the area of the Kingdom of Buton, in addition to the generally rocky soil, there are also obstacles that interfere with crop pests such as monkeys and boars. Although now they 


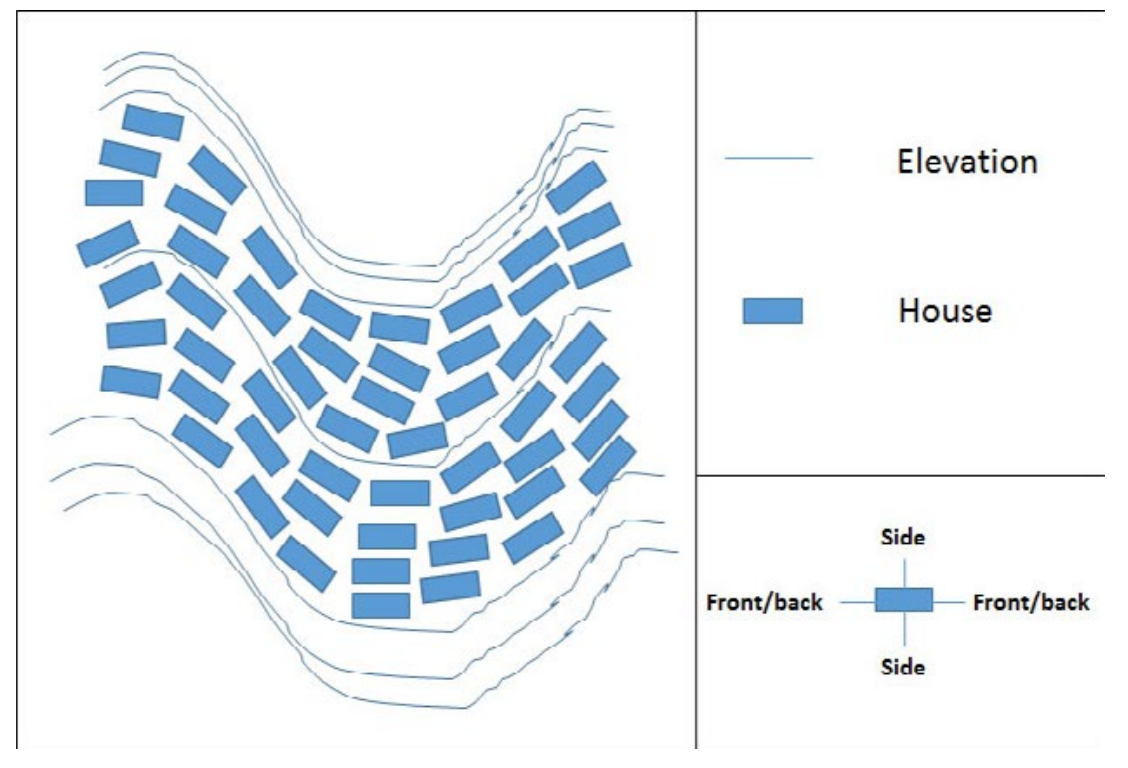

Figure 2. The Orientation of Buton settlements that follow the contours and cliffs

have been hereditary in Maluku so-called natives of the island/ traders (not a native of the area), they still occasionally return to their area (Adam 2010; Barter 2015).

The pattern of settlement orientation as a characteristic of the Butonese cultural landscape in Negeri Kawa has changed. If the orientation of cultural settlement in Buton is determined by the contours, in Negeri Kawa, such consideration does not exist anymore. The situation is caused by several factors. First, Butonese people can freely build without having permission from King of Kawa. Second, the elders do not pass on such knowledge to the next generations. Thirdly, in Buton, there is a division of roles. Pande kau, as the 'architect' of traditional Buton, who is the only group that since ancient times held the duty to take care of everything regarding the house and spatial development, did not join the migration wave. Fourth, the current generation considers it is not so important.

In Buton, the typical orientation patterns can still be found even if only in homes over the age of fifty years, especially around the Palace of Buton. Syahadat, Arifin and Arifin (2014a) assess such orientation pattern. Butonese people do not have the orientation of the wind toward the orientation of their homes as well as other cultures in In- donesia. They mostly follow the contours or in other words accompany the cliff. They believe that such thing brings fortune and energy that come from the mountain/ altitude/sky. By being side by side with the cliff, they hope to hold the fortune that falls from a height (Figure 2). The belief is similar to general beliefs in East Asia.

The orientation of the house in the village inhabited by Butonese ethnic in Negeri Kawa consists of two types: facing the road and facing the sea (Figure 3). According to information from interviews with the Butonese community in Negeri Kawa, their current home orientation has changed. Before, there were roads in the village and the orientation of their home is mostly facing the sea for easy access to sea activities. Different information is found in Dusun Kawa. Since the first time, the orientation of their homes is facing the street. When asked the reasons for facing the road, according to the people who are generally the people of Negeri it is a tradition. So, it is likely that the orientation of the existing Butonese settlements in Negeri Kawa is created by acculturation with the local culture.

The architecture of the Butonese mansion has generally used modern architecture. In Kawa Village, there is no traditional architecture of Buton and Maluku. Last 


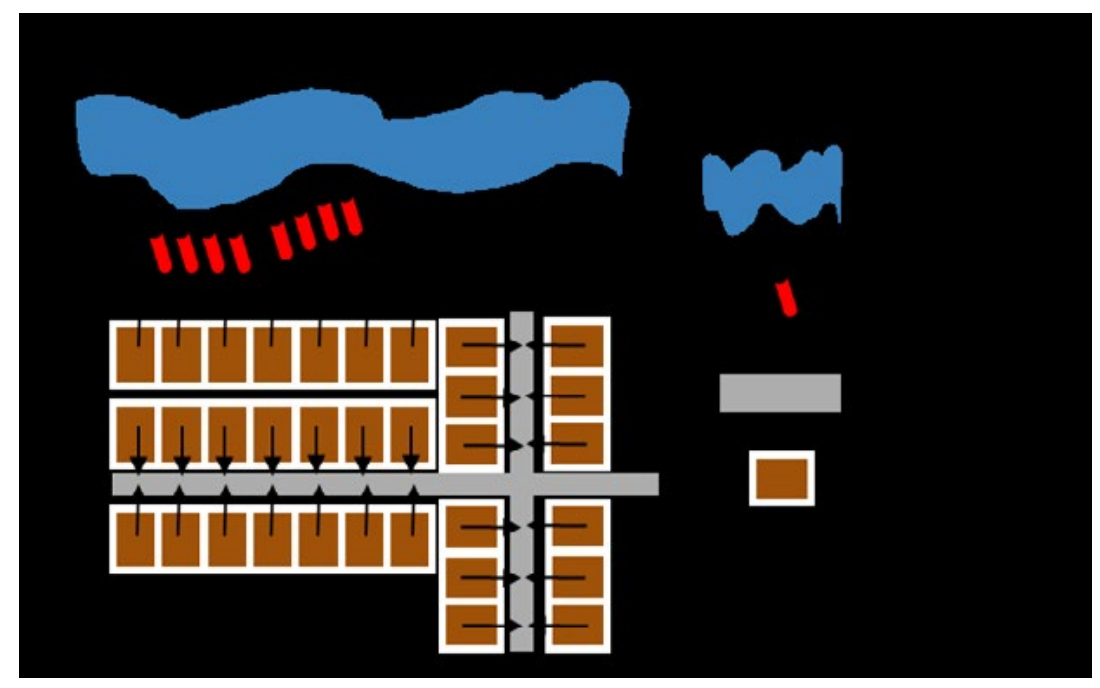

Figure 3. Orientation of Butonese settlement in Kawa Village
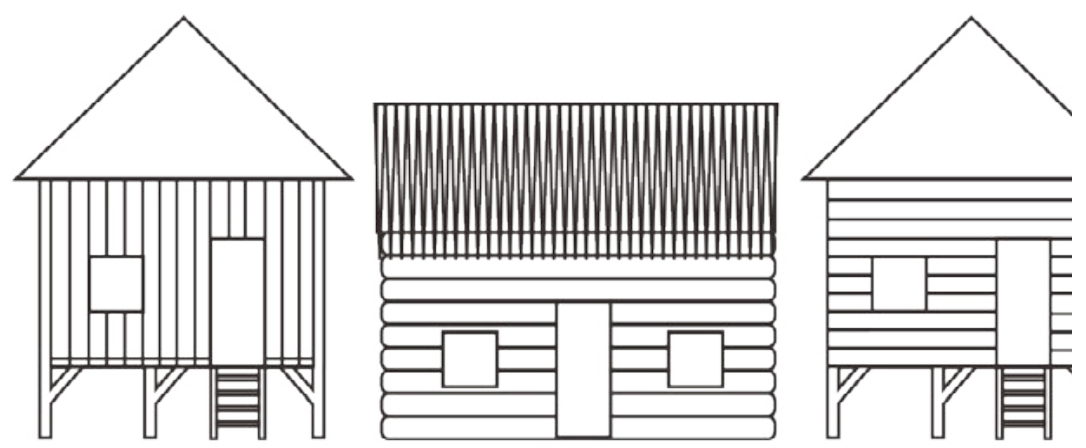

Figure 4. Comparison of architectural forms of banua tada in Buton (a), gaba-gaba balaa (b), and banua tada in Negeri Kawa

time, Maluku traditional architecture called gaba-gaba balaa can be found in the 1980s. The characteristics of the house are for example; the walls are composed of wooden logs and roofed thatch. As for the home of the Buton people in Kawa Village, there is no information about when they were last found. This is also due to the Butonese people in the Kawa Village who mostly came only after the riots of 1999 .

Waeyoho and Pohon Batu villages still have traditional architecture of Butonese for ordinary people named banua tada with typical houses on stilts. As other Butonese traditional houses banua tada also does not use nails but built using interrelated wood. Banua tada still generally survives as a relic of their parents. The difference with banua tada architecture in Buton is that the walls are not vertical but horizontal also which are believed to be adapted from Gaba-gaba balaa house (Figure 4).

The Buton people in building a house should not use an upside-down timber. The top of the tree should be located at the top and the bottom of the tree should be located at the bottom and so the front and rear as well. That is why the view from the outside of the wall of Buton>s house is vertical, not horizontal. There are two factors which cause it. First, the house is like a human body. If we misplace body organs, we create disability. Second, the house serves as a form of homage to the dead tree to feed humans (Syahadat, Arifin, and Arifin 2014 a).

The elements of the Butonese houses in Negeri Kawa also show a little difference. In Negeri Kawa, the Degu-Degu is built in every house. Degu-Degu is a type of gazebo placed right in front of the home 
page (Figure 5). Degu-Degu has several functions. First, it is used by mothers to prepare cooking ingredients. Activities such as cleaning, cutting, until the seasoning process are done in Degu-Degu. Second, DeguDegu is used to relax and chat with friends both among family members and neighbors. Sometimes they also receive guests in Degu-Degu. Third, these elements are used for trading. Butonese people have big sense of entrepreneurship, making them always take advantage of opportunities around. In Degu-Degu, they sell traditional snacks and sometimes herbs that they grow. Degu-Degu stall cannot be said as a stall because the trading conducted by community on Degu Degu occurs spontaneously, which means that if by chance they have/create materials that can be sold.

For Butonese people, the boat is a symbol of life as a home. Previously, it is said that the house for the Butonese people is associated with the human body. This also applies to their boats. When making a boat, the top of the tree should be placed at the top of boat and the bottom must be placed at the bottom (Syahadat, Arifin, and Arifin 2014 a; Maula et al. 2011; Malihu 2011). Butonese community in Negeri Kawa also still makes traditional boat but they have left such principles of the head-bodyfoot boat. As reported by Subair et al. (2014), in Ambon Island, Butonese people also still make and use the boat type of bale-bale. Even in Negeri Kawa, they not only recognize koli-koli, but also jarangka and Bangka /boti/lombo which is also a typical boat from Buton.

Similar to the Lungkak fishing community in East Lombok, Butonese people also have fishermen cultural system from ancestral heritage to new technologies which are both adopted and created by experience (Husain 2011). Without the equipment, Butonese people can detect the islands and corals with the help of clouds, wind and stars (Hamid 2011). The differences with Lungkak fisherman is that Butonese fishermen have left a belief system in the form of rituals such as the original Butonese fisherman in their hometown. The reasons why they leave this system are because of two main things. First, there are no more traditional leaders who take the initiative to run the practice. Second, based on experience and knowledge of nature supported by technological progress without any ritual, they can still get good results.

The only ritual in the fishermen cultural system is Sasi Laut which is carried out by the King of Negeri Kawa. Sasi Laut is one of the rituals that reflect the local wisdom of Maluku community in environmental conservation efforts. This activity aims to

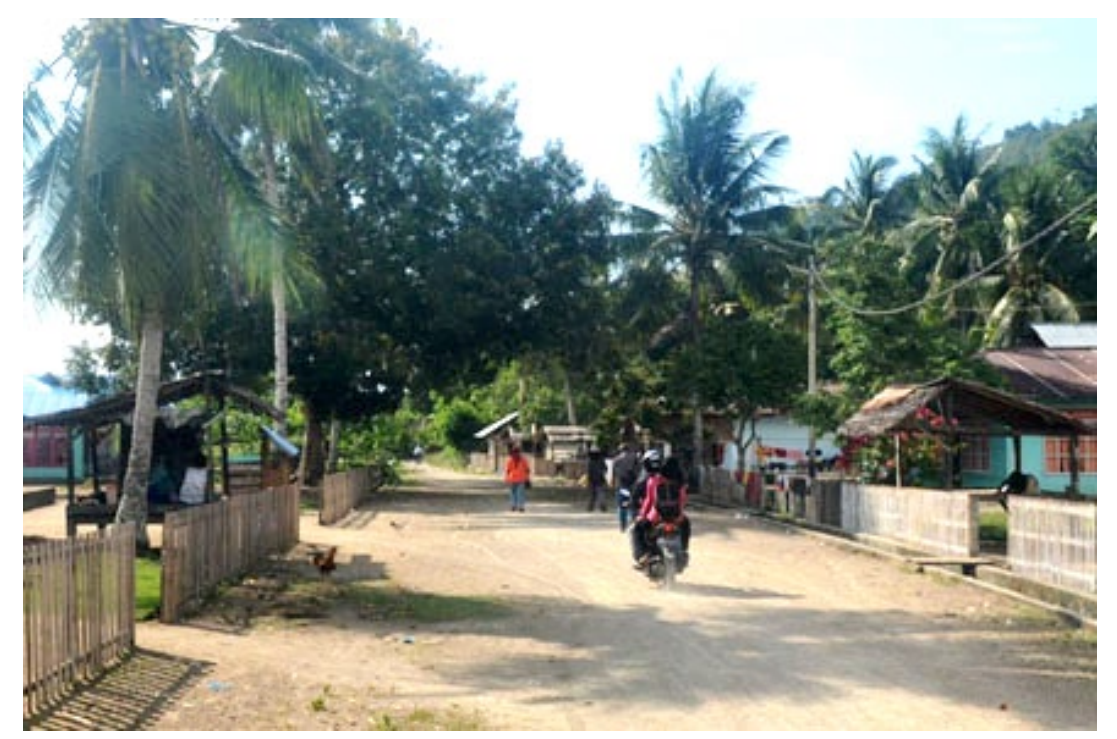

Figure 5.-Degu Degu in the front yard of Waeyoho Village 
protect other living creatures that human beings use to avoid extinction due to continuous exploitation. Sasi laut is done along the coast of Waeyoho to Kawa with a radius of $100-400 \mathrm{~m}$ from the shore. Sasi laut is closed for 1-2 years and opens only for 1 month. Butonese people will have to live it because it is in the community.

\section{Ritual}

Butonese people also have some agricultural rituals (Syahadat, Nuraini, and Safarudin 2014). Similar to the fishermen rituals, the agricultural ritual is also left by Butonese people in Negeri Kawa for the same reason. In contrast to the reasons reported by Palmer (2011), Liwono community in Buton is more influenced by the deepening process of religious and professional transition from farmer to non-farmer professions.

The ritual of Posuo (seclusion) and procedures for marriage are still maintained. It is just that the rules of clothing and makeup which specially characterize Butonese people as well as their philosophical meanings are largely replaced with modern clothing. The modern clothes are suits for men and kebaya for women (Santoso 2010). The reason is not because it is considered not important but because of the unavailability of Butonese customs in Maluku. Only the upper Buton economy people are wearing these clothes because they can rent them directly from Buton, precisely in Baubau City.

Another ritual that has been retained is generally a ritual that has a religious function. The similar report is presented by Aris (2012) in his research on Muna community in Southeast Sulawesi which has a similar cultural style with Buton. The difference with the results of research conducted by Aris and this present study is that a social function does not really affect the sustainability of a ritual. The driving factor of preservation of the ritual is the function of religion while the social function follows behind it.

The arts are quite well maintained i.e. the art of dance and music. This is in line with the results of research by Alkaf (2012) which states the existence of dance is not li- mited by time space, geographical, as well as social culture separations. In addition, the findings in the study area in Negeri Kawa show that people still play Butonese gamelan when there are weddings. Whereas, in Buton itself, the use of Butonese gamelan is slowly replaced by modern musical instruments and only played on special occasions.

Not many people know that Butonese people also have a set of gamelan which is the result of acculturation with Javanese culture. Note that the Kingdom of Buton was founded by three groups from the Chinese Empire, Sriwijaya and Majapahit Kingdoms. One of the cultural heritages of the Majapahit group is in the form of Butonese gamelan. This is confirmed from the book of Negara Kretagama which states that Butun (Buton) is a part of Majapahit (Adji 2013).

Butonese people continue to eat their traditional foods. This is different from the information reported by Ariyani (2013) toward Minang community adaptation of food strategy in Java. Ariyani research results state that the strategies of the Minang people are sifting through selecting food or cooking for themselves. Butonese people are more likely to cook for themselves which makes the typical culinary from Buton is not lost in Negeri Kawa. Even the typical culinary from Buton is able to master Maluku province because the flavored is favored by the them.

It is considerably easy to get a typical culinary of Butonese in Maluku, especially in Negeri Kawa. Culinary like kasoami, katupa santa, parende, typical vegetable of Buton Tawana Kawu, and others are still eaten every day and are even sold by them. The equipment used is also still traditional that they get from Buton. For example, kasoami cookware is made of brass. The tool can only be obtained in Buton and almost every family in Negeri Kawa still owns it.

Buton community in Negeri Kawa used to talk with Indonesian with dialect of Ambon. Although in their group, they rarely use local languages. This happens because Butonese people in Negeri Kawa are as heterogeneous as people in Buton. Buton is not really the name of a particular ethnic but the 
name of a few ethnic groups that used to be part of the Kingdom and the Sultanate of Buton.

Their language is different from one another, just like in Negeri Kawa. They are ethnic Wolio, Sampolawa, Tomia, Kaledupa, Cia-Cia, and so forth. With the existence of a glorious past, they all call themselves Butonese. This becomes the forerunner of ethnographers to classify them into the same ethnic despite the fact that they are different.

In the society system, the head of the village is an extension of King Kawa and appointed directly by him. A village head does not necessarily become the head of customs. The role of the head of customs in every village is to lead a major event that becomes the tradition of the ancestors. In $\mathrm{Bu}-$ ton, each community has its own traditional governance structures and is not equal among each other, but remain in control of the empire. The custom heads of Waeyoho and Pohon Batu are entrusted to the oldest or elderly but have no ties to the Buton Sultanate. Thus, the customary structure of Kawa Village is independent and only for cultural purposes.

Social interaction is an important thing that affects the existence of a community in its environment. Prior to this, Tahara (2012) conducted a study of local ethnic relations in Buton. Syahadat, Arifin, and Arifin (2014 b) have also been doing the study on the relation between newcomer ethnic and local ethnic in Baubau City. Then, how about the relation of fellow Butonese people in their migration area? and how their relation to the original community of the new area?

These results indicate that such stereotypes, preconceptions, and prejudices all happen regardless of which group or where it is located. Stereotypes, presuppositions and prejudices are not always negative. From the explanation of the dynamics of Butonese cultural landscapes in Negeri Kawa, one of the driving factors could be those three reasons.

Since 1999 riots in Maluku, immigrant communities prefer to be on the safe path by not looking for problems that will lead to conflict. It affects their culture. It is seen now that there are a lot of the process of acculturation and adaptation as a form of respect for and adherence to the customs made in the Negeri. These processes indirectly add to the nation>s cultural wealth as reported by Triyanto, Rokhmat, and Mujiyono (2013).

\section{CONCLUSION}

The cultural landscape of Butonese people in Negeri Kawa has some differences with the cultural landscape of Butonese in Buton. The difference is seen from the orientation of the direction of the building on the settlement, the traditional architectural form and also additional elements. The rituals of the tradition of fishing and farming have also been abandoned, but the people follow the rituals of belonging to ethnic Maluku Sasi laut. The rituals that are still well preserved are rituals that have a relationship with religion. Dance, music, and culinary are able to survive very well without any significant change, while the language used is the language with Ambon dialect. The traditions which are slightly different but still characterize the culture of Butonese are Posuo, weddings, and customary governance structures in the village. Stereotypes, presuppositions, and prejudices also occur in Butonese community in Negero Kawa. However, it is not always a negative value because from those three things, the process of acculturation and adaptation as a form of respect and observe the customs made by indigenous people of Negeri Kawa can occur.

\section{REFERENCES}

Adam, J., 2010. Post-Conflict Ambon: Forced Migration and the Ethno-Territorial Effects of Customary Tenure. Development and Change, 41(3), pp. 401-419.

Adji, K.B., 2013. Majapahit (Menguak Majapahit Berdasarkan Fakta Sejarah). Araska, Yogyakarta.

Alkaf, M., 2012. Tari sebagai Gejala Kebudayaan: Studi Tentang Eksistensi Tari Rakyat di Boyolali. Jurnal Komunitas, 4(2), pp. 125-138.

Arifin, E. N., Ananta, A., Wilujeng, W.U., Budi, H.N., \& Pramono, A., 2015. Quantifying Indonesia's 
ethnic diversity: statistics at national, provincial, and district levels. Asian Population Studies, 11(3), pp. 233-256.

Aris, L.O., 2012. Fungsi Ritual Kaago - Ago (Ritual Pencegah Penyakit) pada Masyarakat Muna di Sulawesi Tenggara. Jurnal Komunitas, 4(1), pp. 9-19.

Ariyani, N.I., 2013. Strategi Adaptasi Orang Minang terhadap Bahasa, Makanan, dan Norma Masyarakat Jawa. Jurnal Komunitas, 5(1), pp. 2637.

Barter, S. J., \& Côté, I., 2015. Strife of the soil? Unsettling transmigrant conflicts in Indonesia. Journal of Southeast Asian Studies, 46(1), pp. 6o-85.

Blair, L. \& Blair, L., 2012. Ring of Fire Indonesia dalam Lingkaran Api. Terjemahan T. Balar. Ufuk Press, Jakarta.

Bräuchler, B., 2017. Changing patterns of mobility, citizenship and conflict in Indonesia. Social Identities, 2017(1), pp. 1-16.

Carnegie, M. 2010. Living with difference in rural Indonesia: What can be learned for national and regional political agendas?. Journal of Southeast Asian Studies, 41(3), pp. 449-481.

Hamid, A.R., 2011. Orang Buton Suku Bangsa Bahari Indonesia. Penerbit Ombak, Yogyakarta.

Hidayah, Z., 2015. Ensklopedi Suku Bangsa di Indonesia. Yayasan Pustaka Obor Indonesia, Jakarta. Hidayat, Y. 2013. Hubungan Sosial Antara Etnis Banjar dan Etnis Madura Di Kota Banjarmasin. Jurnal Komunitas, 5(1), pp. 87-92.

Husain, F., 2011. Sistem Budaya Bahari Komunitas Nelayan Lungkak Desa Tanjung Luar, Lombok Timur, Nusa Tenggara Barat. Jurnal Komunitas, 3(1), pp. 40-50.

Kinasih, D., 2013. Interaksi Masyarakat Keturunan Arab dengan Masyarakat Setempat Di Pekalongan. Jurnal Komunitas, 5(1), pp. 38-52.

Koentjaraningrat. 2005. Pengantar Antropologi Jilid II. PT. Rineka Cipta, Jakarta.

Lestari, I.P., 2013. Interaksi Sosial Komunitas Samin dengan Masyarakat Sekitar. Jurnal Komunitas, 5(1), pp. 74-83.

Makmun, L.M.S. Sejarah ekonomi dan perdagangan masa kesultanan. dalam: Fahimuddin M.M (Eds). 2011. Menafsir Ulang Sejarah dan Budaya Buton. Penerbit RESPECT, Baubau.

Malihu, L., 2011. Buton dan tradisi maritim. in $\mathrm{Fa}-$ himuddin, M.M (ed) Menafsir Ulang Sejarah dan Budaya Buton. Penerbit RESPECT, Baubau.

Maula, M.J., Rudyansjah, T, Prahara, H., \& Ratri, S.D.
2011. Kesepakatan Tanah Wolio: Ideologi Kebhinekaan dan Eksistensi Budaya Bahari di Buton. Titian Budaya, Depok.

Palmer, B., 2011. Petani dan Pedagang: Perubahan Ekonomi dan Agama di Buton. Antropologi Indonesia, 32(1), pp. 65-81.

Riyanti, P., 2013. Relasi Sosial Pedagang Etnis Cina dan Etnis Jawa di Pasar Tradisional. Jurnal Komunitas, 5(1), pp. 53-63.

Santoso, T., 2010. Tata Rias dan Busana Pengantin Seluruh Indonesia. Gramedia Pustaka Utama, Jakarta.

Simonds, J.O. \& Starke, B.W. 2006. Landscape Architecture: A Manual of Environmental Planning and Design. The McGraw-Hill Companies, New York.

Subair, Kolopaking, L. M., Adibowo, S., \& Pranowo, M.B., 2014. Adaptasi Perubahan Iklim Komunitas Desa: Studi Kasus di Kawasan Pesisir Utara Pulau Ambon. Jurnal Komunitas, 6(1), pp. 57-69. doi:http://dx.doi.org/10.15294/komunitas.v6i1.2943.

Subair. 2014. Merayakan Satu Dekade Pasca Konflik: Hidup Harmonis dalam Bingkai Segregasi. Jur-nal Studi Islam, 3(1), pp. 72-85.

Syahadat, R.M, Arifin, N.H, \& Arifin, H.S., 2014. Boat Pattern on Landscape of Baubau City, A Phylosophy Design by Ancestor. International Symposium Waterfront Asian Cultural Landscape. Seoul. 7 - 9 October 2014.

Syahadat, R.M, Arifin, N.H, \& Arifin, H.S., 2014. Public Perception on Historical Landscape of Ethnic Immigrant Heritage in Heritage City of Baubau. Jurnal Komunitas, 6(1), pp. 312-319. doi:http://dx.doi.org/10.15294/komunitas. v6i2.3310.

Syahadat, R.M., Nuraini, \& Safarudin. 2014. Pertanian Organik Labalawa, Sebuah Kearifan Lokal Berusia Ratusan Tahun di Kota Baubau Provinsi Sulawesi Tenggara. Prosiding Seminar Nasional Pertanian Organik. Bogor. 18 - 19 Juni 2014.

Tahara, T., 2012. Reproduksi Strereotip Orang Katobengke dalam Struktur Masyarakat Buton. Antro-pologi Indonesia, 33(2), pp. 75-97.

Triyanto, Rochmat, N., \& Mujiyono. Warak Ngendog: Simbol Akulturasi Budaya pada Karya Seni Rupa. Jurnal Komunitas, 5(2), pp. 162-171. 